\title{
ASSESSING THE IMPACT OF OUTBREAKS ON MALAYSIAN LISTED PROPERTY COMPANIES IN MIXED-ASSET PORTFOLIOS
}

\author{
Muhammad Najib Razali \\ Faculty of Built Environment and Surveying \\ Universiti Teknologi Malaysia \\ e-mail:mnajibmr@utm.my \\ Rohaya Abdul Jalil \\ Faculty of Built Environment and Surveying \\ Universiti Teknologi Malaysia \\ e-mail: rohaya@utm.my
}

\author{
Ahmad Faisal Shayuti \\ Faculty of Built Environment and Surveying \\ Universiti Teknologi Malaysia \\ e-mail:afas_260675@yahoo.com
}

\begin{abstract}
This paper assesses the impact of outbreaks from the perspective of volatility of Malaysian Listed Property Companies in mixed-asset portfolios, concentrating on periods of time between outbreaks. The real issue of this study is the health crisis that has troubled institutional investors, as it has already significantly impacted the returns on investments. Investors need to be better informed on the impact of health outbreaks on investments in order to minimize their impact. To assess the impact of the outbreaks, the GARCH method has been employed to examine the dynamic volatility of listed property companies in mixed-asset portfolios. The volatility level will give investors better information from point of view of the dynamics of volatility of the Malaysian listed property companies' performance within mixed-asset portfolios. The findings show that listed property companies demonstrate high volatility compared to other mixed-asset portfolios during the periods of outbreaks. This indicates Malaysian listed property companies were the most volatile investment in mixed-asset portfolios. This empirical study will contribute significantly to institutional investors, especially in terms of the investment decision-making process during outbreaks.
\end{abstract}

Keywords: outbreaks, Malaysia, listed property companies, mixed-assets, property portfolio.

JEL Classification: C58.

Citation: Razali, M. N., Jalil, R. A., \& Shayuti, A. F. (2021). Assessing the impact of outbreaks on Malaysian listed property companies in mixed-asset portfolios. Real Estate Management and Valuation, 29(3), 87-93.

DOI: https://doi.org/10.2478/remav-2021-0024

\section{Introduction}

The recurrence of several outbreaks such as H1N1 Severe Acute Respiratory System (SARS), Middle East Respiratory Syndrome Coronavirus (MERS-COV) and Coronavirus (COVID-19) have had a significant impact on global economic growth. According to Bonheure et al. (2006), a pandemic was 


\section{S sciendo}

said to have the chance of occurring in about 30 years. This is evident today, as outbreaks are still occurring. These outbreaks are able to create recessions at the global level, which has a drastic effect on humanity. This is due to the unpredictable situation, which depends on the effectiveness of a country's measures for overcoming the situation. Several measures, such as quarantine, travel restrictions, businesses temporarily closing, stimulus packages and increases for healthcare in budgets will have an impact on the social, economic, financial and administrative sectors. Given the scale of the pandemic or epidemic, the impact will be very significant and can create unstable condition to the economic situation. Historically, several global outbreaks which have significantly impacted economic growth have hit Malaysia. One of the major outbreaks in this decade was SARS, which was first detected in Guangdong, China. SARS has been considered one of the major endemics which affected 26 countries and resulted in more than 8,000 cases in 2003 . This endemic put many businesses in a bad situation in term of revenue and profit. As seen with the SARS outbreak, the lack of preparedness among public companies resulted in devastating effects on businesses (Day et al., 2004). It can be seen that the sectors which suffered the most were tourism, airlines and retail. Real estate sectors, which are sensitive to the situation, such as economic and political, have also been impacted by the outbreaks. According to a study by Chou et al. (2004) on the impact of the SARS outbreak, securities and real estate sectors in Taiwan fell by $26.1 \%$ and $7.7 \%$ respectively. Hong Kong retail sales were down $80 \%$ to $90 \%$, restaurants and their suppliers were going broke and hotel occupancy rates were in the single digits (Day et al., 2004).

\section{Literature Review}

\section{Outbreaks Impact}

Relevant research which relates to health issues had been carried out previously, although it has not focused on property securitized markets. Several researchers investigated the impact of the outbreak on the local economy. Brennan et al. (2004) investigated the impact of SARS on emerging markets. The findings revealed that emerging markets, such as China, experienced GDP drop below 7\%, which was the lowest in the decade. Moreover, as emerging markets have also become major suppliers for natural resources, businesses of industrialized nations therefore experience serious implications. Another study related to the SARS pandemic was done by Overby et al. (2004) which assessed the impact of the outbreaks on Southeast Asian countries. The study revealed that SARS triggered the perception among investors that this continent was a riskier place to invest. Interestingly, the report also mentioned that SARS created positive economic benefits for some companies by utilizing online applications, triggered by the fear to travel to Southeast Asian countries. The e-commerce medium for retail business boomed during the post-SARS pandemic, which require less travel and face-to-face meetings.

Other researchers, such as Zika (Castro et al., 2017), Avian Flu Influenza (Dreyer, 2007) and Mumps Outbreak (Kutty et al., 2014), also investigated other outbreaks. Generally, the findings of these studies were that the outbreaks had a financial impact not just on the people, but also the countries' financial systems. The outbreaks have had a negative effect on investment values, liquidity in assets and investment strategies, and hedged investment instruments have been put in place to mitigate the risk of an outbreak (Dreyer, 2007). This is due to the governments' need to allocate more money into public health services, such as vaccines, money to support activities such as active surveillance, case information, contact tracing, communication with other affected areas, issuance of press releases, issuance of health advisories, public health education, and research and development (Kutty et al., 2014). These measures are essential to restoring domestic economic activities, which consequently improve foreign investor confidence.

The year 2020 was supposed to be a new decade, where all countries aimed to be more successful than in the previous decade. Nevertheless, the world has been outraged by a new virus known as Coronavirus or COVID-19. The World Bank warned that Asian countries will face the prospect of a "'third shock" to follow the trade war and the new Coronavirus outbreak (World Bank, 2020). The report also stated that the shock could cripple the financial sector and capital markets, which are very important, as vital sources of liquidity for reviving industries as well as other sectors.

The main motivation of this paper is to draw the dynamic of volatility for the property security market as this type of investment has become very active in recent years. Portfolio managers need the ability to manage risk as well as anticipate various types of risk, including outbreaks. This is because it 
seems outbreak events have become more frequent in recent years, as discussed in the previous section. It is important for fund managers to assure business continuity and absorb the impact from spillovers and unprecedented volatility. The information on volatility will provide contingency plans in the spectrum of risk and capability to counter high-impact catastrophes. The ability to manage emerging risks, anticipate interactions between different types of risk and bounce back from disruption will be a competitive differentiator for companies and countries alike in the $21^{\text {st }}$ century (Council of Competitiveness, 2007).

\section{Significant of Listed Property Companies during Outbreaks}

The impact of globalisation has brought about vital market information which will emphasise the reality of the seriousness of the situation. The impact from frequent outbreak events on the economy is undeniable. Although the immediate impact has been very evident in the retail and hospitality sectors; certain industries are more susceptible to the disruption of supply chains (JLL, 2020). The securities' sector, including property which is sensitive to economy sentiment, will also be eventually disrupted. The longer the outbreaks, the more likely securities markets are to face interruptions, which, consequently, spills over onto other sectors. Previous research only concentrated on the dynamics of volatility from the perspective of a financial crisis. The COVID-19 pandemic has triggered financial markets to also be prepared for outbreaks. Businesses are not only required to prepare for financial crises emergencies, but also disease outbreaks. This is particularly important for financial markets, where businesses are one of the pillars of economic growth and employment opportunities. This includes mitigation and resilience costs in business strategies to react quickly to an unprecedented situation, such as an outbreak.

An unprecedented event, such as outbreak is difficult to predict. This is because the impact continues to grow and needs long-term planning, especially for the real estate sector (CBRE, 2000). Globalisation has had a severe knock-on effect on supply chains in the financial system, which are characterized by distress transmission channels between banks, assets and interbank markets (Idier \& Piquard, 2017). During an outbreak, these three different parties will be severely impacted, which subsequently impacts the property securities market.

\section{Methodology}

This paper will analyze the performance of listed property companies and mixed-asset portfolios comprising of shares, industries, bonds, finances, agricultural and cash from January 2000 to March 2020. Data for this study extracted from Thomson Reuters DataStream comprises listed property companies, shares, agricultural, industrial, finances and bonds. Table 1 tabulated the details of the characteristics of the data.

Table 1

Research Data

\begin{tabular}{|c|c|c|c|c|c|c|}
\hline $\begin{array}{l}\text { Property } \\
\text { companies }\end{array}$ & Shares & Bonds & $\begin{array}{l}\text { Industrials } \\
\text { Sector }\end{array}$ & $\begin{array}{l}\text { Finances } \\
\text { Sector }\end{array}$ & $\begin{array}{l}\text { Plantations } \\
\text { Sector }\end{array}$ & $\begin{array}{l}\text { Cash } \\
\text { Sector }\end{array}$ \\
\hline FTSE Bursa & FTSE & Mala & $\begin{array}{ll}\text { FTSE } & \text { Bursa }\end{array}$ & FTSE Bursa & FTSE Bursa & Malaysia \\
\hline Malaysia & Bursa & Government & Malaysia & Malaysia & Malaysia & Treasury \\
\hline Properties & Malaysia & Securities & Industrial & Finance & Plantation & Discount \\
\hline Sector & KLCI & $\begin{array}{l}\text { Medium } \\
\text { Term }\end{array}$ & Sector & Sector & Sector & $\begin{array}{l}\text { Rate - } 3 \\
\text { months }\end{array}$ \\
\hline
\end{tabular}

Source: Thomson Reuters DataStream (2021).

Although the time series is still brief yet for COVID-19 analysis, according to Central Limit Theorem by Johnson (2004), a conservative definition of a sufficiently large sample size is $n$ greater or equal to 30. Therefore, the range period between December 2019 and March 2020 is sufficient for a time-series analysis. GARCH models will be used in this research to determine time-varying conditional variances and covariance. The GARCH model is parsimonious allowing for long memory in the volatility process and suitable in most time series analyses (Bollerslev et al., 1992). The ultimate analysis of volatility co-movement has to be done using a systematic approach, for example analyzing volatility of the Malaysian property stocks market and comparing it with other mixed-asset portfolios. 
A multivariate GARCH model will capture the dynamics of volatility between Malaysia and other mixed-asset portfolios.

This method will measure precedence and information content, but does not, in itself, indicate causality in the more common use of the term. This research attempts to measure a cyclic pattern which is related to infectious disease events that have characteristics of heteroscedasticity or nonconstant standard deviations in a time-series. According to Wang et al. (2002) the advantage of the GARCH approach is that the model estimates more efficient methods, which leads to better statistical properties. In addition, it investigates possible changes in conditional variances of the returns for all mixed-asset classes which provide information useful to financial market observers and investors. $\mathrm{GARCH}$ also assesses the time-varying volatility in the mean equation and variance equation. Granger causality testing in this research is calculated by using EViews software. EViews runs bivariate regression in the form of:

$$
\begin{aligned}
& Y_{\mathrm{t}}=\propto_{0}+\propto_{1} \mathrm{y}_{\mathrm{t}-1}+\ldots \propto_{1} \mathrm{y}_{\mathrm{t}-1}+\beta_{1} \mathrm{x}_{\mathrm{t}-1}+\ldots \beta_{1} x_{-1}+\varepsilon_{\mathrm{t}} \\
& x \mathrm{t}=\propto_{0}+\propto_{1} \mathrm{x}_{\mathrm{t}-1}+\propto_{1} \mathrm{x}_{\mathrm{t}-1}+\beta_{1} \mathrm{y}_{\mathrm{t}-1}+\ldots .+\beta_{1} \mathrm{y}_{-1}+\mu_{\mathrm{t}}
\end{aligned}
$$

for all possible pairs of $(x, y)$ series in a group. The reported F-statistics are the Wald statistics for the joint hypothesis:

$$
\begin{aligned}
& \beta_{1}=\beta_{2}=\ldots \beta_{1}=0 \\
& \beta_{1}=\beta_{2}=\ldots \beta_{1}=0
\end{aligned}
$$

\section{Findings}

This section presents the empirical results to assess the dynamics of volatility issues in the mixed-asset class portfolio markets. The GARCH method is aimed at identifying if there is a linear combination of two or more series. It will also identify the volatility process as an indicator of volatility convergence between two asset classes which are responding to similar factors causing the volatility. Table 2 exhibits the findings from the GARCH (1.1) model for the listed property company returns for panAsian countries over the period from January 2000 to March 2020. The findings indicate the conditional mean coefficients for listed property companies within mixed-asset portfolios over this period. Prior to the GARCH test, a unit root test had been used to ensure the stationarity to all variables. In addition, the GARCH specification is appropriate for capturing the presence of timevarying volatility. The results suggested that the GARCH specification failed to model the volatility for bonds, plantation and industrial. In contrast, GARCH (1.1) was successful in modelling the volatility over this period for shares, property companies and finances. The volatility persistence indicated by $(\alpha+\beta)$ for those assets comprises 0.998394 (shares), 0.71887 (property companies), and 0.76238 (finance). These indicate high persistence and a slow decay of the volatility shocks for these assets over the period of the study. For all indices, the volatility was high during this period, thus indicating higher standard deviations for all indices. The results were expected during the financial crisis period as Malaysia experienced the GFC as well as other major outbreaks such as SARS and H1N1 which stimulated high volatility. The results were consistent with an earlier study by Chau and Newell (1997) and Liow (1997), who commented that, when it comes to property companies in Asia including Malaysia, markets were riskier and more volatile due to the high proportion of property activities in regional development. Gabaix et al. (2016) also mentioned that institutional investment activities played a role in volatility conditions of the market. The results also correspond with findings by Liow (2008), who found some volatility persistence in Malaysian property securitized markets.

The recent COVID-19 pandemic has shocked the world with a significant impact on the economy. Almost all countries have imposed lockdown measures which have an effect on economic activities and growth. This unprecedented event has already taken its toll with some major indicators in economies showing negative impacts, such as job losses, negative growth in retail industries, paralyzed tourism sectors and collapsing share markets. According to a report by McKinsey \& Company (2020), the COVID-19 crisis has epochal disruptions on economic systems, posing a threat to lives as well as livelihoods. The report also mentioned reassessments of downturn scenarios, typically span revenues, the stability of supply chains, general options, and liquidity needs. Therefore, it is anticipated that portfolio companies will battle to survive due to the impact of the pandemic. The findings revealed some high volatility trends from December 2019 to December 2020. From the 
outputs, GARCH $(1,1)$ only failed to model bonds and plantations. These two portfolio assets still seem able to show resilience towards the latest pandemic. On the contrary, the GARCH (1.1) was found to model shares, property companies and industrial assets successfully.. The volatility persistence indicated by $(\alpha+\beta)$ for these assets was 0.85232 (shares), 0.83516 (property companies), 1.04704 (finance) and 0.76953 (industrial). This signifies a high persistence and slow decay of volatility shocks over other asset classes. Although the COVID-19 pandemic was only detected a few months ago, the results have showed the impending severe impact that this virus will have on the portfolio market, in particular in Malaysia. The full results are tabulated in Table 3.

Table 2

Diagnostics for GARCH $(1,1)$ Model for listed property companies in pan-Asian countries: January 2000 - December 2020

\begin{tabular}{lccccccc}
\hline & Shares & $\begin{array}{c}\text { Property } \\
\text { companies }\end{array}$ & Bonds & Plantation & Finance & Industrial & Cash \\
\hline $\begin{array}{l}\text { Mean } \\
\text { equation }\end{array}$ & & & & & & & \\
\hline $\mathrm{C}$ & 0.001520 & 0.001621 & 0.000432 & 0.000312 & 0.015345 & 0.000326 & 0.001432 \\
& $(0.0154)$ & $(0.0151)$ & $(0.0031)^{* *}$ & $(0.0021)^{* *}$ & $(0.0158)$ & $(0.0029)^{* *}$ & $(0.0293)$ \\
\hline Variance & & & & & & & \\
equation & & & & & & & \\
\hline$\omega$ & 0.054590 & $1.04 \mathrm{E}-02$ & $4.65 \mathrm{E}-25$ & 0.45393 & 0.58395 & 4.38493 & $2.15 \mathrm{E}-01$ \\
& $(0.0000)$ & $(0.0217)$ & $(0.0000)^{* *}$ & $(0.0184)^{* *}$ & $(0.0254)$ & $(0.0002)^{* *}$ & $(0.0301)$ \\
\hline$\alpha$ & 0.163944 & 0.17495 & 0.160454 & 0.12593 & 0.17843 & 0.05940 & 0.17385 \\
& $(0.0000)$ & $(0.0001)$ & $(0.0001)^{* *}$ & $(0.0000)^{* *}$ & $(0.0001)$ & $(0.0000)^{* *}$ & $(0.0000)$ \\
\hline$\beta$ & 0.83445 & 0.54392 & 0.643234 & 0.53244 & 0.78394 & 0.73942 & 0.59495 \\
& $(0.0000)$ & $(0.0000)$ & $(0.0000)^{* *}$ & $(0.0000)^{* *}$ & $(0.0000)$ & $(0.0001)^{* *}$ & $(0.0000)$ \\
\hline
\end{tabular}

** indicate failure to improve likelihood

$P$-value is given in parenthesis

Note: $\sigma_{t}^{2}=\omega+\sum a_{t-1} \beta \sigma^{2} t-1+\sum p_{t-1} a \varepsilon^{2} t-1$

Table 3

Diagnostic for the GARCH (1.1) Model for listed property companies in pan-Asian countries: COVID19 (Dec 2019- December 2020)

\begin{tabular}{|c|c|c|c|c|c|c|c|}
\hline & Shares & $\begin{array}{c}\text { Property } \\
\text { companies }\end{array}$ & Bonds & Plantation & Finance & Industrial & Cash \\
\hline \multicolumn{8}{|c|}{$\begin{array}{l}\text { Mean } \\
\text { equation }\end{array}$} \\
\hline C & $\begin{array}{l}0.003213 \\
(0.0000)\end{array}$ & $\begin{array}{l}0.001421 \\
(0.0141)\end{array}$ & $\begin{array}{l}0.000410 \\
(0.0023)^{* *}\end{array}$ & $\begin{array}{l}0.001490 \\
(0.0000)^{\star *}\end{array}$ & $\begin{array}{l}0.013244 \\
(0.01214)\end{array}$ & $\begin{array}{l}0.000214 \\
(0.0019)\end{array}$ & $\begin{array}{l}0.001312 \\
(0.0245)\end{array}$ \\
\hline \multicolumn{8}{|c|}{$\begin{array}{l}\text { Variance } \\
\text { equation }\end{array}$} \\
\hline$\omega$ & $\begin{array}{l}0.02456 \\
(0.0000)\end{array}$ & $\begin{array}{l}1.02 \mathrm{E}-01 \\
(0.0321)\end{array}$ & $\begin{array}{l}3.21 \mathrm{E}-10 \\
(0.0000)^{* *}\end{array}$ & $\begin{array}{l}2.22 \mathrm{E}-02 \\
(0.0184)^{* *}\end{array}$ & $\begin{array}{l}0.4321 \\
(0.01242)\end{array}$ & $\begin{array}{l}0.0002 \\
(0.0000)\end{array}$ & $\begin{array}{l}1.03 \mathrm{E}-02 \\
(0.0301)\end{array}$ \\
\hline a & $\begin{array}{l}0.10311 \\
(0.0000)\end{array}$ & $\begin{array}{l}0.15323 \\
(0.0000)\end{array}$ & $\begin{array}{l}0.15213 \\
(0.0001)^{* *}\end{array}$ & $\begin{array}{l}0.12354 \\
(0.0000)^{* *}\end{array}$ & $\begin{array}{l}0.15313 \\
(0.0001)\end{array}$ & $\begin{array}{l}0.03139 \\
(0.0000)\end{array}$ & $\begin{array}{l}0.15311 \\
(0.0000)\end{array}$ \\
\hline$\beta$ & $\begin{array}{l}0.74921 \\
(0.0000)\end{array}$ & $\begin{array}{l}0.68193 \\
(0.0000)\end{array}$ & $\begin{array}{l}0.59103 \\
(0.0000)^{* *}\end{array}$ & $\begin{array}{l}0.74921 \\
(0.0000)^{* *}\end{array}$ & $\begin{array}{l}0.89391 \\
(0.0000)\end{array}$ & $\begin{array}{l}0.73813 \\
(0.0001)\end{array}$ & $\begin{array}{l}0.3194 \\
(0.0000)\end{array}$ \\
\hline
\end{tabular}

** indicate failure to improve likelihood 


\section{S sciendo}

P-value is given in parenthesis

\section{Conclusions}

Understanding the behavior of local major portfolio markets is vital for a country like Malaysia. A study of this behavior, particularly during a financial crisis, which highlights that the cause of the crisis is a pandemic, has become extremely important in the recent years. It has been observed that global financial markets hit by the impact from outbreaks need to especially pay attention to information regarding the performance of securities markets as it involves the investors' money. Investors anticipate profit when they invest money in portfolio markets. Therefore, information regarding a situation which was caused by the outbreaks that would affect the investment is imperative. The COVID-19 situation has been worrying investors and they thus need to be familiar with the resilience of the local portfolio market to outbreaks. A few decades ago, outbreaks became an occurrence which forced investors and relevant stakeholders to prepare for such events in the future.

The main objective of this paper is to investigate the volatility level of listed property companies within mixed-asset portfolios by using modern series techniques to develop diagnostic testing. In highlighting COVID-19, which has resulted in economic downturn in many countries, it is a high priority for policies-maker and industry players to possess information regarding market dynamics, especially volatility levels. This information will help relevant stakeholders to be well-prepared for future outbreaks. Previous outbreaks have impacted the global economy in the short-term for economic growth and individual activities. Global outbreaks have occurred in patterns from which it can be anticipated that more outbreaks will strike in the future. It is therefore suggested that a scenario for planning is essential for a country to be ready to rebound its economic growth.

Overall, the research has provided significant input, especially in assessing the behavior of the securities market in response to outbreaks as well as a financial crisis. In facing a new decade, Malaysia has to put more strength into the domestic economy, including listed property companies. With a series of outbreaks, the strength of the domestic economy is vital to ensure that a recovery process from outbreaks takes place within a short period of time. Furthermore, the literature background regarding the performance of the listed property companies and their thorough analysis, especially on the volatility levels of listed property companies and other mixed-asset portfolios, is still limited. This paper will enrich the literature in terms of rigorous analyses in understanding the listed property companies in Malaysia.

\section{References}

Bollerslev, T., \& Wooldridge, J. M. (1992). Quasi-maximum likelihood estimation and inference in dynamic models with time-varying co-variances. Econometric Reviews, 11(2), 143-172. https://doi.org/10.1080/07474939208800229

Bonheure, K., Keller, P., \& Somers, K. (2016). Avian flu: Expanding global vaccine production. McKinsey Weekly Web Exclusive.

Brennan, D., McKay, R. B., \& Michael, I. (2004). "It Will Happen Again" What SARS Taught Business about Crisis Management. Management Decision, 42, 822-836. https://doi.org/10.1108/00251740410550907

Castro, M. C., Wilson, M. E., \& Bloom, D. E. (2017). Disease and economic burdens of dengue. The Lancet. Infectious Diseases, 17(3), e70-e78. https://doi.org/10.1016/S1473-3099(16)30545-X PMID:28185869

Chau, K. W., \& Newell, G. (1997). Reaching into Asia: The dynamics of the Hong Kong commercial property market. Valuer and Land Economist, 34(6), 522.

Chou, J., Kuo, N. F., \& Peng, S. L. (2004). Potential impacts of the SARS outbreak on Taiwan's economy. Asian Economic Papers, 3(1), 84-99. https:// doi.org/10.1162/1535351041747969

Council of Competitiveness. (2007). Annual Competitiveness Report 2007. Dublin.

Day, B., McKay, R. B., Ishman, M., \& Chung, E. (2004). The new normal: Lessons learned from SARS for corporations operating in emerging markets. Management Decision, 42, 794-806. https://doi.org/10.1108/00251740410542357

Dreyer, A., Kritzinger, G., \& Decker, J. D. (2007) Assessing the Impact of a Pandemic on the Life Insurance Industry in South Africa. In 1st IAA Life Colloquium, Stockholm. 
Gabaix, X., Laibson, D., Li, D., Li, H., Resnick, S., \& de Vries, C. G. (2016). The impact of competition on prices with numerous firms. Journal of Economic Theory, 165, 1-24. https://doi.org/10.1016/i.jet.2016.04.001

Idier, J. \& Piquard, T. (2017) Pandemic crises in financial systems: a simulation-model to complement stress-testing frameworks. https:// doi.org/10.2139/ssrn.2916617

Johnson, O. (2004). Information theory and the central limit theorem. World Scientific. https://doi.org/10.1142/p341

Kutty, P. K., McLean, H. Q., Lawler, J., Schulte, C., Hudson, J. M., Blog, D., \& Wallace, G. (2014). Risk factors for transmission of mumps in a highly vaccinated population in Orange County, NY, 20092010. The Pediatric Infectious Disease Journal, 33(2), 121-125. https:// doi.org/10.1097/INF.0000000000000020 PMID:23995590

Liow, K. H. (1997). The historical performance of Singapore property stocks. Journal of Property Finance, 8(2), 111-125. https://doi.org/10.1108/09588689710167816

Liow, K. H. (2008). Extreme returns and value at risk in international securitized real estate markets. Journal of Property Investment \& Finance, 28(6), 434-453. https:/ / doi.org/10.1108/14635781011080294

McKinsey \& Company. (2020). How private equity operating groups are taking on the challenge of the coronavirus.

https://www.mckinsey.com/ /media/mckinsey/industries/private\%20equity\%20and\%20princi pal\%20investors/our\%20insights/how\%20private\%20 equity\%20operating\%20groups\%20are\%20ta king\%20on\%20the \%20challenge $\% 20$ of $\% 20$ the $\% 20$ coronavirus/how-private-equity-operatinggroups-are-taking-on-the-challenge-of-the-coronavirus-vf.pdf?shouldIndex=false

Overby, J., Rayburn, M., Hammond, K., \& Wyld, D. C. (2004). The China syndrome: The impact of the SARS epidemic in Southeast Asia. Asia Pacific Journal of Marketing and Logistics, 16, 69-94. https://doi.org/10.1108/13555850410765131

Wang, Z., Salin, V., Hooker, N. H., \& Leatham, D. (2002). Stock market reaction to food recalls: A GARCH application. Applied Economics Letters, 9(15), 979-987. https://doi.org/10.1080/13504850210148125

World Bank. (2020). East Asia and Pacific: Countries Must Act Now to Mitigate Economic Shock of COVID19. 